\title{
Community Development in Kemijen Village, East Semarang: A Corporate Social Responsibility in Practice
}

\author{
Hartuti Purnaweni ${ }^{1,2}$, Irzaldi Yazid ${ }^{3}$, Mutia Nur Arifah ${ }^{3}$, and Anis Qomariah ${ }^{2}$
}

\author{
${ }^{1}$ Department of Public Administration, Faculty of Social and Political Science, Diponegoro University, Semarang; \\ e-mail: hartutipurnaweni@gmail.com \\ ${ }^{2}$ Master and Doctorate Program of Environmental Science, School of Postgraduate Studies, Diponegoro University, \\ Semarang \\ ${ }^{3}$ Departement of Business Administration, Faculty of Social and Political Science, Diponegoro University, \\ Semarang
}

\begin{abstract}
Companies, either state-owned and private which operates in the field and/or related to natural resources must implement Corporate Social Responsibility (CSR), such as by PT Indonesia Power (PT. IP) UBP-Tambaklorok which is located nearby Tanjung Mas Harbor, Tambaklorok Village, North Semarang District. Semarang City. The CSR implementation should benefit for both sides, the company for its image and the local community for the implemented programs. Therefore it is important to analyse perception of the local community as well as their opinions about the company's CSR activities in their village, in this case is the people of Kemijen village which is located adjacent to the PT. IP's area. This research is descriptive qualitative, done in 2019, describing the phenomenon of CSR implementation by PT. IP, and the perception of the local community of Kemijen village towards the CSR activities implemented by PT. IP. The informants were taken using purposive sampling technique, covering both formal and informal leaders, the local people, as well as community development officer of PT. IP. Primary data was gathered using in-depth interview technique and observation. Secondary data consist of documents. Primary and secondary data was then coded and analysed interactively. PT. IP has formulated and implemented the Company's strategies into CSR Roadmap 2015-2019, which is the grand strategy and a milestone of CSR implementation to integrate CSR strategy into the Company's strategy, in the sectors of education, health, economy, and infrastructure. According to the perception of the Kemijen villagers, there have been both benefit and insufficiency of the PT. IP's CSR implementation. They expect more programs to be implemented, in order to allowing them more opportunities for poverty alleviation.
\end{abstract}

Keywords: CSR, Local people’s peception, Education, Health, Infrastructure, Economy

Citation: Purnaweni, H., Yazid, I., Arifah, M. N., and Qomariah, A. (2021). Community Development in Kemijen District, North Semarang: A Corporate Social Responsibility in Practice. Jurnal Ilmu Lingkungan, 19(1), 83-88, doi:10.14710/jil.19.1.83-88

\section{Introduction}

People, profit and planet as elements of the triple bottom line should be implemented in a balanced and concurrent manner to achieve sustainable development. Instead of synergizing, these elements often intersect with each other due to conflicts of interest (Hadi, 2020). In most cases, the planet is the weakest element with the least number of supports compared to the other two elements (Hammer \& Pivo, 2017). This is because the planet is still not considered a basic need that must be met. On the other hand, human being live in such a situation that they are in really need the environment. It is the human who depends on the environment rather than the opposite. In fulfilling all their needs, human interact one to another by making exchange. It is where economic activities take place. Producers take resources from the environment, and then provide goods and services to the consumers as the users.

In their operational activities companies, especially when their production related to natural resources, usually create unavoidable social and environmental consequences. Therefore, these companies must allocate parts of their revenues for social and environmental activities, especially to the affected communities nearby the companies' operational locations. It is compulsory in Indonesia according to Law Number 40 Year 2007 on Limited Liability Company, 2007 in which in the Chapter V Article 74 Paragraph 1 says that "companies operates in the field and/or related to natural resources must implement Corporate Social Responsibility (CSR)". Thus, CSR is considered as a way to synergize the triple bottom line pillars (Hadi, 2020).

All corporates must commit to the community development. This role is executed by all corporates, either state-owned or private-own. One of those having been performing the Corporate Social Responsibility (CSR) is PT Indonesia Power (PT. IP).

As has been stated in research done by Ma'rif et al. (2013) the manufacturing companies tend to implement their CSR around these companies. PT. IP 
Purnaweni, H., Yazid, I., Arifah, M. N., and Qomariah, A. (2021). Community Development in Kemijen District, North Semarang: A Corporate Social Responsibility in Practice. Jurnal Ilmu Lingkungan, 19(1), 83-88, doi:10.14710/jil.19.1.83-88

Tambaklorok Semarang CSR activities are in the villages of Kemijen, Bandarharjo, Tambaklorok, and in Tanjung Emas, besides in Gunungpati which is quite far from the company location in North Semarang but still in the city of Semarang. There are several articles on CSR on mangrove in Tambaklorok village, milkfish (bandeng) fish in Tanjung Emas, and fish fumigation in Bandarharjo. However there was very limited articles on CSR in Kemijen village. There are also articles on the CSR of PT. Indonesia Power in some cities. However, only a few focused on CSR of Indonesia Power in Semarang, which are CSR creative in natural batik as Indonesia Power's commitment in environment and cultural development of people in Gunungpati village, western Semarang (Martuti et al, 2017; Naryoso, 2020).

Therefore, this study contains an assessment of the community development in Kemijen Village, Semarang Municipality, by PT Indonesia Power (PT. IP) UBP Semarang in particular, based on the perception of the local community in Kemijen Village towards PT Indonesia Power, as well as their opinions about the company's CSR activities in this village.

\section{Method}

The type of this research is descriptive qualitative, describing the phenomena of CSR implementation by PT. Indonesia Power (IP) UBPTambaklorok as it has been known since it is located at Tambaklorok, Semarang City. This research was conducted in 2019.

The CSR is aimed at community development effort for the local people living around the company, especially in this research is people in Kelurahan Kemijen (Kemijen Village). Therefore, locus of this research is at Kelurahan Kemijen, and the focus is the phemonemon especially seen among the local people of Kemijen. The phenomenon is the implementation of CSR by PT. IP Semarang and the perception of the local community of Kemijen village towards the CSR activities implemented by PT. IP.

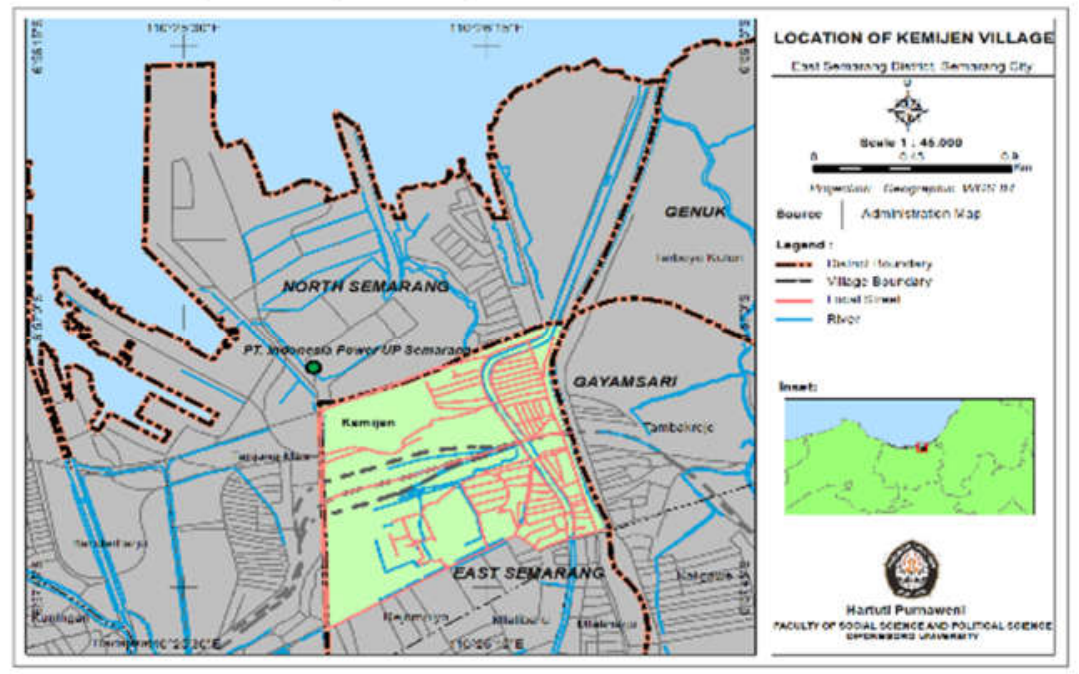

Figure 1. Location of Kemijen Village and PT. IP

The informants were taken using purposive sampling technique, covering prominent formal (Head of the village), informal leaders ( wife of head of the village as Head of Women Asociation), the local adult people in general, as well as community development officer of PT. IP company. They were chosen since they were considered having the capacity to give needed data and information. Data was gathered using indepth interview technique with the informants, as well as informal interview on relevant interest with several local communities, besides observation of the existing social and physical facts in the Kemijen village areas. Documents and analysis of secondary data were also utilized.

Triangulation technique was also applied to get a valid data by using other sources (material, people) for comparing collected data. Information from one source was checked with information from other sources. Primary (interview results and observation) and secondary data (from the village) was then coded and analyzed interactively using Miles et al. (2014) technique, then qualitatively analyzed.

\section{Results and Discussion}

Apart from supporting the implementation of sustainable development, several studies have shown that CSR is also beneficial for companies to build employee trust and enhance the company's reputation (Naryoso, 2020; Yadav et al., 2018). According to Wibisono (2007), there are five pillars covered in CSR activities, as follows: (a) capacity building of manpower both inside the company and in the surrounding community; (b) enhancing local community economic condition; (c) inharmonious relational cooperation between the company and its social environment could create conflict; (d) developing good corporate governance; (e) physical, social and cultural sustainability. In this research, the term "...and in the surrounding community" is very important to notice, since this is one among the main 
reasons for Indonesia Power's CSR in its surrounding villages

CSR is applied through three strategies, namely: (1) Community Relations. Which is done through activities support the development of understanding by means of communication and information to stakeholders. In this way that CSR prograns are directed into short term and accidental charity activcities. (2) Community Service. Focused on company service to meet the societal needs. The company is the facilitator, while the society is empowering themselves. (3) Community Empowering. This CSR strategy gives broader access to the society to support its empowerment, which they become the company's partner (Budimanta et al., 2008; Hadi, 2020).

Community service and community empowerment are very important related to community relations of the company with its surrounding communities.

Hadi (2020) stated that community empowerment or community development is the highest level and the most complicated CSR's strategies because it requires accompaniment, planning, and good governance. CSR becomes the spearhead of signing a Community Development towards mutual wealth between business, society, and environment. The affected community must be encouraged to take an active role in the interaction. In principle, community should become the beneficiary of any business activity. The community involvement in development has become an integral part of democratic political system. Furthermore, development must accord with environmental sustainability.

All corporates must commit to the community development, including the application of Corporate Social Responsibility (CSR) is PT Indonesia Power (PT. IP), an energy company, which provides electricity in Java and Bali Islands. The PT. IP has some offices as operational locations in Java and Bali. There have been some researches on CSR done about PT. IP as part of study on several companies in Semarang, Central Java, including PT. IP ( Ma'rif et al., 2013), PT. IP in East Java covering PT. IP in Kamojang (Muhammad et al., 2019) and in Suralaya, Banten (Efendi et al., 2020; Nugroho \& Purnaweni, 2020), PT. IP UPJ PLTU Jeranjang West Lombok (Supija et al., 2018). There is also an article found on the CSR of PT. IP Tambaklorok Semarang (Hendro S \& Naryoso, 2018; S. \& Naryoso, 2020). The papers mostly talk about the CSR programs of PT. IP, satisfactory index, and community respons to the CSR programs.

PT Indonesia Power Tambaklorok is located at Tanjung Mas Harbor, Semarang, in Tambaklorok Village, Semarang Utara District. The other villages nearby the company are Tanjung Mas, Kemijen, and Bandarharjo. This study focuses on an effort to find out how the company performs its community development in Kemijen Village only, as this location becomes one of the the CSR core territoritories of PT Indonesia Power (PT. IP) of Semarang branch.
Regulations require a mandatory compliance of any enterprise or corporate to exercise activities aimed at developing the nearby environment. The Corporate Social Responsibility (CSR) is one of examples promoted by PT Indonesia Power UBPTambaklorok Semarang across the nearby area, i.e. the area where its stakeholder live and feel the direct impacts of the corporate daily activities.

PT Indonesia Power has performed several CSR activities concerning the affected environment in Bandarharjo, Kemijen dan Tanjung MaS villages. These villages have been traditionally receiving immediate impacts of the business activities of PT Indonesia Power UBP-Tambak Lorok. Therefore, based on the reasons stated in the Introduction, Kemijen village was the location of this research.

Kemijen Village is a crowded community, inhabited by 3.924 people, grouped into 11 RWs (Rukun Warga, or big neighbourhood compound), consist of 82 RTs (Rukun Tetangga) of smaller neighbourhood compound (Semarang City, 2020).

\subsection{CSR Implementation in Kemijen Village}

The business run by Indonesia Power is of very important to the society. Electricity is the main energy source very much needed by human being for everyday's life, ranging from lighting, energy for so many appliances, heating, transportation, communication, to entertainment of various activities (television, film, cellular phone). No one could imagine life without electricity. Therefore, the position of Indonesia Power as electricity provider is very important

As an energy company that brings direct impact on the life of the society, Indonesia Power continues to seek to provide product and service that meet customer expectation and are environmentally friendly. This is carried out by synergizing its business activities in environment, employment, occupational health and safety management, as well as responsibility to the customers and social development of the community to support improvement of life quality and better environment. Environment and nature sustainability guarantee smooth business process and ensure availability of raw materials supply that are sourced from the nature.

In order to achieve business continuity, Indonesia Power has formulated and implemented the Company's strategies into CSR Roadmap 2015-2019, which is the grand strategy and a milestone of CSR implementation to integrate CSR strategy into the Company's strategy. In addition, Indonesia Power is always committed to implement sustainability programs through CSR activities and a series of policies that aim to realize sustainable development.

The most crucial economic sector in Kemijen Village, according to male local leaders, is that the village is lacking skilled employments, most making their livings as laborers, hampering self-manifestation of the localities. Kemijen Village, furthermore, is still 
deficient in terms of educational quality, creating poor responsiveness to up-to-date knowledge.

The environmental issue is found in the lack of trees in the village. This area needs more green strips to support their life quality. To worsen the situation, health quality also tends to be inadequate. Most of the local community cannot afford to buy necessary medicines or medical checks-up. Waste problem also contributes to the poor condition across Kemijen, in which defecation facilities are absent.

Therefore, female local community activitists and leaders noted that they want improvement in health sector service, in particular Integrated Service Post (Pos Pelayanan Terpadu, or Posyandu). Posyandu is very important to secure adequate nutrition for infants and elderly. This Posyandu activities is monthly run, with local volunteers manage the events. However, it needs supplys such as healthy snacks or food for the elderly and the infants. Wife of the Head of Kemijen village, who was also head of the Local Women Group expected that Posyandu can be available in each RW group of .

Table 1. Priority needed by Kemijen community and CSR of PT Indonesia Power

\begin{tabular}{|c|c|}
\hline Sector & Problems \\
\hline \multirow[t]{5}{*}{ Economy } & $\begin{array}{l}\text { Members of each RW have different skills and expertises, so that a } \\
\text { clear mapping is necessary. The CSR should focus on economy, } \\
\text { education, infrastructure, and health. }\end{array}$ \\
\hline & $\begin{array}{l}\text { 2. Many youths in Kemijen are still unemployed. Some of them have } \\
\text { gone as far as becoming unskilled workforces, hampering them to } \\
\text { get a better life condition. }\end{array}$ \\
\hline & $\begin{array}{l}\text { 3. The most important issue in our neighbourhood is local economic } \\
\text { improvement because Kemijen is still dominated by unskilled and } \\
\text { pre-welfare human resources. Trainings are necessary to help them } \\
\text { get better opportunities. Business management education will be } \\
\text { valuable for the local people to prepare themselves in the } \\
\text { employment arena }\end{array}$ \\
\hline & $\begin{array}{l}\text { 4. Kemijen needs facilities that provide and serve local processed foods } \\
\text { to be marketed outside the village }\end{array}$ \\
\hline & $\begin{array}{l}\text { 5. Financial grants are necessary to materialize Kampung Terampil } \\
\text { mission that helps Kemijen have a good image. The village is } \\
\text { traditionally well-known as unsafe to live since it has security } \\
\text { problems }\end{array}$ \\
\hline
\end{tabular}

Education

Health

1. Many children are unable to attend good schoolings. A free-of-charge education is necessary to help them out.

2. Most of them are secondary to high school graduates.

3. A building renovation with more convenient and conducive environment is necessary for Early Education Center

1. The village is in need for Posyandu that provides complimentary diets, which are important for the infants' growth.

2. In addition, complimentary diets can also be targeted to elderly.

Infrastructure 1. Waste management is a disturbing problem so that it needs immediate actions towards healthier environment

2. Machine-based waste management is ineffective when the electricity does not work, in particular when the flood occurs. Therefore, the village need an integrated waste channel to prevent the waste from polluting the environment

3. Flood prevention still becomes a serious problem because some of the dwellers are in dispute with PT KAI in terms of the rights on the settlement. According to the village chief, it deals with economic and infrastructure aspects

4. In terms of infrastructure, the village is planning to build an entry gate (gapura) to beautify the look. The local people have been making effort of creating the clean and creative neighborhood. Whereas, economic speaking, the villagers are attempting to create entrepreneurship in small or large groups. These groups are coordinated by experienced individuals and aided by external fundings.

5. The financial aspect becomes the major problem towards longlasting entrepreneurship of the villagers.
1. Development and Empowerment Program for Family Welfare Movement (PKK) through Waste Bank in collaboration with Cooperatives and SMEs Office of Semarang Municipality, PKPU, and UNNES in 2019 with the funding worth IDR 20,000,000 (Pemerintah Kota Semarang, 2019)

2. 979 basic food assistance packages for residents in 3 urban villages affected by Covid-19 in collaboration with IZI Semarang in 2020 (Berita Ekspres, 2020).

3. Coastal Community Empowerment Program for processing milkfish into presto product (Hendro S \& Naryoso, 2018)

1. University Scholaship for 1 Kemijen student in collaboration with Education Office of Semarang Municipality in 2019 with the funding worth IDR $7,000,000$

1. Supplementary feeding program for the elderly in collaboration with Health Office of Semarang Municipality for 50 elderlies worth IDR 5,000,000 in 2019

1. Provide water pumps to suck up floodwaters in 2020 (Mata Fakta, 2021)

2. Build waste bank buildings to support Waste Bank activity (Ellya, 2017)

Data Taken From Interviews, Mass Media, and Public Data

Kemijen villagers have already been familiar with PT Indonesia Power since they were kids. Therefore, they expect that the company gives a specific attention to the local villagers by making a priority during the job recruitment. On the other hand, most of the villagers do not qualify for the job specifications, which are dominated by electrical engineering skills. PT Indonesia Power is very selective in recruiting the applicants, since the very technical system it has. However, with 13,97 \% out of its households are categorized into poor families, the Kemijen villagers are mostly low educated people, do not suit with the 
company's requirements. Still, some of the villagers perception is that the company does not give priority to the local people.

Table 1 explains the priorities they villagers expect from PT Indonesia Power's CSR and the CSR Programs as a respon to it.

From the Table 1, we know that PT. IP has done some CSR Programs as a respons to local community priority problems. However, there are still some priority issues that have not been resolved through the CSR program. In economic sector, there is only 2 training programs provided for local residents in improving their economy (waste bank and milk fish processing). It is not sufficient since people nowadays are dealing with information and technology problems. Skills in IT sectors are highly requested for local community to sell their products broadly through online system.

In education sector, CSR Program one provided scholarship for 1 university student. In the CSR reporting web, they stated that the scholarship is available for 2 students but only 1 student fitted the requirements. It shows that the education quality in Kemijen Village is not good but they can not afford tutoring fees. So, it is important to provide free group study for Kemijen students. Furthermore, they need to renovate the school building as expected by the local community.

In health sector, PT. IP has responed to the local community problems very well. They have provided supplementary program for 50 elderlies in 2019 in collaboration with Health Office of Semarang Municipality.

In infastrusture sector, CSR Programs are done by build Waste Bank building and provide water pumps to suck up floodwaters. It really helps the local community since flood and waste are the main problems of their community. However, local community expects more than curative strategy like water pumps. They expect preventive strategy to flood because flood happens often.

\subsection{Local Community Perception of CSR Programs}

In general, the local people of Kemijen Village perceived PT Indonesia Power to have a goodwill but the implementation of its community programs should have been better. Such inadequacy has prompted the community to demand more from the company in order to help them out of dependency. PT Indonesia Power is expected to make the best effort to help grow and improve the life quality of Kemijen Villagers.

PT Indonesia Power, furthermore, had also contributed by providing books and scholarship to the local children and students, but the local community had not been proactively involved in any decisionmaking process. Table 2 shows local community opinios on CSR Programs of PT Indonesia Power.

From Table 2, it shows that the main problems in CSR implementation in Kemijen are: a) inequality in contribution and grant, and b) inappropriate grant. For this reason, PT IP needs to involve local residents starting from the planning stage of the CSR program to find out about the priority issues of residents. In addition, it is necessary to carry out an evaluation that also involves residents so that the next CSR program will be more effective, equitable and right on target.

Table 2. Opinions on PT Indonesia Power's Company Social Responsibility

\begin{tabular}{lll}
\hline \hline No. & \multicolumn{1}{c}{ Problem } & \multicolumn{1}{c}{ Description } \\
\hline 1. & $\begin{array}{l}\text { Inequality in } \\
\text { contribution and } \\
\text { grant }\end{array}$ & $\begin{array}{l}\text { Most of the villagers reported that } \\
\text { grant provided by PT Indonesia } \\
\text { Power had not been equal, being } \\
\text { concentrated in only a few RWs. }\end{array}$ \\
\hline $2 . \quad \begin{array}{l}\text { Inappropriate } \\
\text { grant }\end{array}$ & $\begin{array}{l}\text { The local villagers expected that the } \\
\text { company has big impacts on their } \\
\text { economic life by allowing them } \\
\text { more opportunities to alleviate } \\
\text { from the poverty. }\end{array}$ \\
\hline
\end{tabular}

Data Taken from Interviews

\section{Closing}

\subsection{Summary}

According to perception of the Kemijen villagers, there are many sectors mostly needed by the local villagers, in terms of economic, education, and health that needs to be resolved through the CSR programs. In the education sector, the local villagers need bigger allocation for scholarship.

In the health sector, PT. IP has responded to the local community problems very well, by providing supplementary program for 50 elderlies in 2019 in collaboration with Semarang Health Office.

In infrastructure sector, PT. IP's CSR Programs was done by constructing Waste Bank building, besides providing water pumps to manage the floodwaters which has been helping the local community since flood and waste are the main problems of the Kemijen community.

In the economic sector, waste bank and milk fish processing by PT. IP was not sufficient.

\subsection{Recommendation}

PT. IP should conduct better educational programs in Kemijen village such as facilitating free group study for Kemijen students and bigger fund for scholarship. The company should also renovate the school building as expected by the local community.

In the health sector, the loval villagers need better support for their Posyandu programs.

In terms of infrastructure development, local community expects more than curative strategy like water pumps. They expect preventive strategy to flood since flood is a latent threats in the local area.

The CSR grants should also be better distributed, in order to allowing the local villagers more opportunities to alleviate them from poverty.

\section{REFERENCES}

Berita Ekspres. 2020. Program CSR, PT. IP Bersama IZI Bagikan 979 Paket Sembako di 3 Kelurahan. 
Budimanta, A., Prasetijo, A., dan Rudito, B. 2008. Corporate Social Responsibility: Alternatif Bagi Pembangunan Indonesia. ICSD.

Efendi, A., Alqudsiyy, I. I., dan Nugroho, K. S. 2020. Pemberdayaan Masyarakat oleh PT. Indonesia Power Suralaya Power Generation Unit: Omah Kreteg Anggana. Jurnal Administrasi Publik, Vol. 11 No. 1. Hal. 92-101.

Ellya. 2017. Indonesia Power Resmikan Gedung Bank Sampah.

Hadi, S. P. 2020. Tanggung Jawab Sosial dan Lingkungan Perusahaan. Undip Press.

Hammer, J., and Pivo, G. 2017. The Triple Bottom Line and Sustainable Economic Development Theory and Practice. Economic Development Quarterly, Vol. 31 No. 1. Pages 25-36.

Hendro S, D., and Naryoso, A. 2018. Development of Corporate Social Responsibility (CSR) Model of Productive Independent Business Establishment of Marina Resources Management (Case Study of PT. Indonesia Power UP Semarang). 3rd International Conference of Graduate School on Sustainability, September. Pages 57-74.

Law Number 40 Year 2007 on Limited Liability Company, Ps. 1.

Ma'rif, S., Sugiri, A., Waskitaningsih, N., dan Hayati, R. N. 2013. Kajian Kebijakan Corporate Social Responsibility (CSR) di Kota Semarang. Riptek, Vol. 7 No. 2. Hal. 11-36.

Martuti, N.K.Tri, Etty Soesilowati, Muh Fakhrihun dan Na'am, 2017. Pemberdayaan Masyarakat Pesisir Melalui Penciptaan Batik Mangrove, Jurnal Abdimas, Vol. 21 No. 1. Hal. 65-74.

Mata Fakta. 2021. PT. IP Semarang PGU Kirim Bantuan Pompa Air ke Warga Kemijen.
Miles, M. B., Huberman, A. M., and Saldaña, J. 2014. Qualitative Data Analysis: A Methods Sourcebook (3rd ed.). SAGE Publications.

Muhammad, C. I., Raharjo, S. T., dan Resnawaty, R. 2019. Pelaksanaan Corporate Social Responsibility PT. Indonesia Power Upjp Kamojang. Share : Social Work Journal, Vol. 8 No. 2. Pages 195-202.

Naryoso, A. 2020. Relationship Between CSR Quality with Corporate Reputation PT Indonesia Power UP Semarang. Advances in Social Science, Education and Humanities Research, Vol 423. Pages 1-16.

Naryoso, A, 2020. Komitmen Lingkungan dan Budaya CSR Kreatif Multitema Batik Alam Malon PT Indonesia Power Semarang Power Generation Unit, Jurnal Ilmu Komunikasi Acta Diurna, Vol. 16 No. 1.

Nugroho, K., amd Purnaweni, H. 2020. Community Satisfaction Index in Coastal Community Empowerment by PT. Indonesia Power Generation Unit (UP) Suralaya, Cilegon-Banten in 2018. 2015.

Pemerintah Kota Semarang. 2019. Profil CSR \& PKBL PT. Indonesia Power Semarang Power Generation Unit.

S., D. H., dan Naryoso, A. 2020. Komitmen Lingkungan dan Budaya CSR Kreatif Multitema Batik Alam Malon PT Indonesia Power Semarang Power Generation Unit Darmawan. Acta Diurna, Vol. 16 No. 1. Hal. 92-101.

Supija, B. A., Rahmat, L. A., dan Y, Y. T. S. 2018. Corporate Social Responsibility Perusahaan PT Indonesia Power UJP PLTU Jeranjang dalam Mengurangi Kemiskinan. JCommsci: Journal of Media and Communication Science, Vol. 1 No. 1. Hal. 1-14.

Wibisono, Y. 2007. Membedah Konsep \& Aplikasi CSR (Corporate Social Responsibility). Gramedia.

Yadav, R. S., Dash, S. S., Chakraborty, S., and Kumar, M. 2018. Perceived CSR and Corporate Reputation: The Mediating Role of Employee Trust. Vikalpa, Vol. 43 No. 3. Pages 139-151. 